\title{
FIRST DESCRIPTION OF THE MALE OF PHILOMETRA FILIFORMIS (NEMATODA: PHILOMETRIDAE), A GONAD-INFECTING PARASITE OF THE MARINE FISH PAGELLUS ERYTHRINUS (SPARIDAE) IN MEDITERRANEAN
}

\author{
Gabriella Gaglio $^{1}$, Salvatore Giannetto ${ }^{1}$, Antonio Panebianco ${ }^{1}$ and František Moravec ${ }^{2}$ \\ ${ }^{1}$ Dipartimento Sanità Pubblica Veterinaria, Facoltà Medicina Veterinaria, Polo Universitario dell'Annunziata, 98168 Messina, Italy; \\ ${ }^{2}$ Institute of Parasitology, Biology Centre of the Academy of Sciences of the Czech Republic, Branišovská 31, 37005 České \\ Budějovice, Czech Republic
}

\begin{abstract}
The male of the gonad-infecting nematode Philometra filiformis (Stossich, 1896) (Philometridae) is for the first time described, based on specimens from the ovary of the marine fish Pagellus erythrinus (Linnaeus) from the Tyrrhenian Sea off Sicily, Italy. It is mainly characterized by the testis extending anteriorly nearly to the anterior end of body, the oesophagus without a usual anterior inflation, the absence of a dorsal barb or distinct transverse lamellae on the tip of the gubernaculum, the measurements of the spicules and the gubernaculum, and a fairly long body.
\end{abstract}

Stossich (1896) poorly described Ichthyonema (= Philometra) filiformis from the Adriatic Sea (Triest, Italy), based on young female specimens collected in the ovaries of Pagellus erythrinus (Linnaeus) (Sparidae) and those of Trachinus draco Linnaeus (Trachinidae). Later it was reported by Kostina (1961) from Spicara smaris (Linnaeus) (Centracanthidae) from the Black Sea and by Orecchia and Paggi (1978) from Trachinus draco from Italy, but no species description was given. Moravec and Genc (2004) questioned the identifications of specimens from $S$. smaris and T. draco and provided an incomplete redescription of $P$. filiformis based on body fragments of a single gravid female found in the ovary of the type host (P. erythrinus) from North-East Mediterranean (Iskanderun Bay) near Turkey. A more complete redescription of $P$. filiformis gravid and subgravid females, based on specimens from $P$. erythrinus in the Tyrrhenian Sea off Sicily, Italy, was given by Moravec et al. (2008a). The male of this species has not been described to date.

A total of 14 specimens of $P$. filiformis ( 8 males and 6 nongravid females) was found in the ovary of one common pandora, Pagellus erythrinus (total body length $19.5 \mathrm{~cm}$, weight 83 $\mathrm{g}$ ), from the Tyrrhenian Sea off Sicily, Italy, examined in June 2009. Their light microscopy examination made it possible to describe, for the first time, the previously unknown male of this insufficiently known species. Males and females of gonad-infecting Philometra spp. are known to have the same location (gonads) in the host; considering a high degree of host specificity of philometrids, it is apparent that the males of the present material belong to $P$. filiformis. A voucher specimen is deposited in the Helminthological Collection of the Institute of Parasitology, BC ASCR, České Budějovice (Cat. No. N-808).

Description of Philometra filiformis male (based on 2 specimens) (Fig. 1): Body filiform, whitish, 5.22-5.40 mm long, maximum width at middle $87-90 \mu \mathrm{m}$, somewhat tapering at both ends. Width of cephalic end 27-30 $\mu \mathrm{m}$, of caudal end 24-27 $\mu \mathrm{m}$. Cuticle smooth. Cephalic end rounded, cephalic papillae indistinct. Oesophagus 366-405 $\mu \mathrm{m}$ long, forming about $7 \%$ of body length, not inflated at anterior end; posterior part of muscular oesophagus overlapped by well-developed oesophageal gland with large cell nucleus in middle. Oesophageal nucleus and nerve ring 249-279 $\mu \mathrm{m}$ and $147-168 \mu \mathrm{m}$, respectively, from anterior extremity. Excretory pore $222-240 \mu \mathrm{m}$ from anterior end. Testis reaching anteriorly to short distance $(27 \mu \mathrm{m})$ posterior to anterior extremity, overlapping thus major part of oesophagus. Posterior end of body somewhat narrowed, blunt, with slightly lobular, U-shaped mound; 1 pair of preanal, 1 pair of adanal, and 1 pair of postanal, very flat and hardly visible caudal papillae present. Spicules slender, needle-like, nearly equally long, with somewhat expanded proximal and sharply pointed distal ends; length of spicules $90-93 \mu \mathrm{m}$, representing $1.7 \%$ of body length. Gubernaculum narrow, smooth, 69-81 $\mu \mathrm{m}$ long, with its nearly proximal half somewhat dorsally bent; length of anterior bent part 30-36 $\mu \mathrm{m}$, representing $43-44 \%$ of entire gubernaculum length; distal end of gubernaculum without dorsal barb or distinct transverse lamellae. Length ratio of gubernaculum and spicules 1:1.15-1.30. Spicules and gubernaculum well sclerotized; spicules orange-brown, gubernaculum colourless.

It has recently been indicated that the male morphology is substantial for the correct species identification of gonad-infecting species of Philometra (see Moravec et al. 2008b, c, 2009a, Moravec and Justine 2008, 2009, Quiazon et al. 2008a, b and Moravec and de Buron 2009a). Despite that these widely distributed parasites of marine and brackish-water fishes are severely pathogenic and can affect fish reproduction (Clarke et al. 2006, Quiazon et al. 2008b), most species are known only by largesized, morphologically rather uniform females, whereas the very small conspecific males, which may be helpful for species identification, have not yet been discovered; this also concerns other philometrids (e.g., Moravec 2006, Moravec and de Buron 2009b, Moravec et al. 2009a, b, c).

As found in this study, characteristic morphological features of $P$. filiformis are the testis extending anteriorly nearly to the anterior end of body, overlapping thus a major part of the oesophagus, the oesophagus without a usual anterior inflation (characteristic also of conspecific females), the absence of a dorsal barb or distinct transverse lamellae on the tip of the gu- 

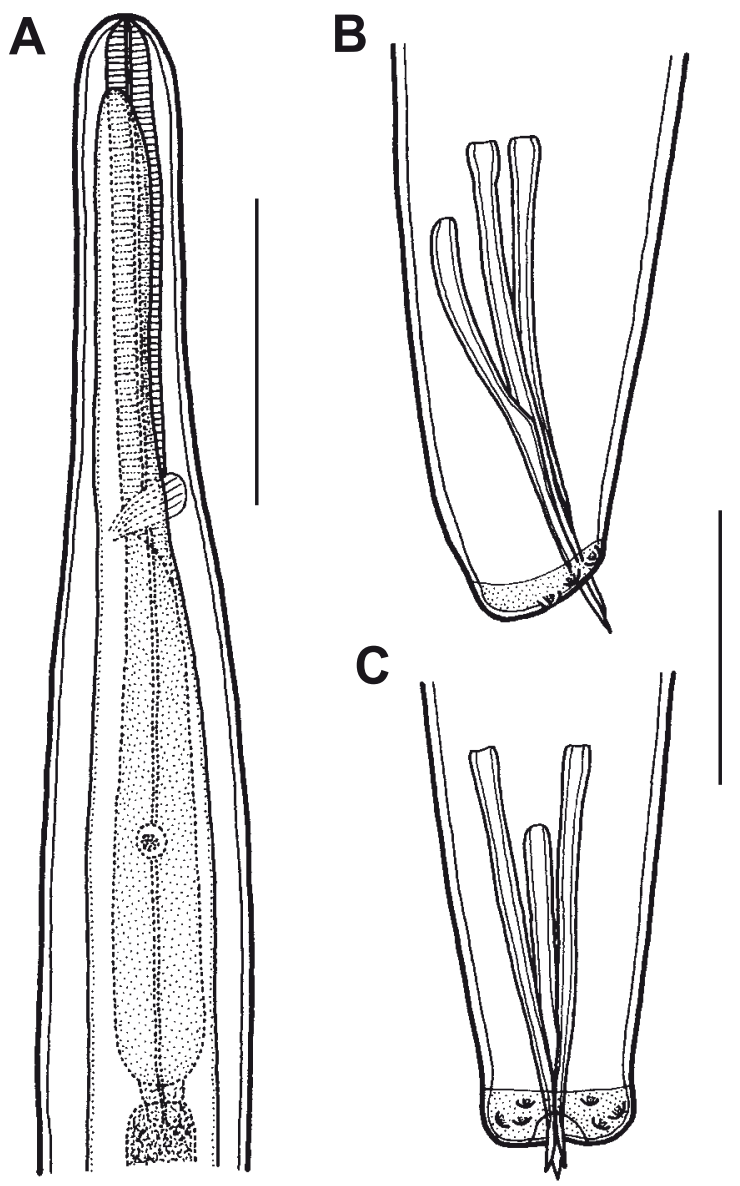

Fig. 1. Philometra filiformis (Stossich, 1896), male. A - anterior end of body, lateral view; $\mathbf{B}, \mathbf{C}$ - caudal end, lateral and ventral views, respectively. Scale bars: $\mathrm{A}=100 \mu \mathrm{m} ; \mathrm{B}, \mathrm{C}=50 \mu \mathrm{m}$.

bernaculum, the measurements of spicules and gubernaculum, and a fairly long body. By the combination of these features, $P$. filiformis males can be distinctly distinguished from those of other congeneric species in which the male is known.

Authors wish to thank Irena Husáková from the Institute of Parasitology, Biology Centre of the ASCR, České Budějovice for her help with illustrations. This study was partly supported by research projects of the Institute of Parasitology, ASCR (Z60220518 and LC522).

\section{References}

Clarke L.M., Dove A.D.M., Conover D.O. 2006: Prevalence, intensity, and effect of a nematode (Philometra saltatrix) in the ovaries of bluefish (Pomatomus saltatrix). Fish. Bull. 104: 118-124.

Kostina T.A. 1961: [Parasite fauna of the Black Sea picarel Spicara smaris (L.).] Tr. Sevastopol. Biol. Stantsii 14: 274-285. (In Russian.)

Moravec F. 2006: Dracunculoid and Anguillicoloid Nematodes Parasitic in Vertebrates. Academia, Prague, 634 pp.

Moravec F., Charo-Karisa H., Jirků M. 2009a: Philometrids (Nematoda: Philometridae) from fishes of Lake Turkana,
Kenya, including two new species of Philometra and erection of Afrophilometra gen. sp. Folia Parasitol. 56: 41-54.

Moravec F., De Buron I. 2009a: New data on three gonad-infecting species of Philometra (Nematoda, Philometridae) from estuarine fishes in South Carolina, USA. Acta Parasitol. 54: 244-252.

Moravec F., DE Buron I. 2009b: Two new species of philometrids (Nematoda: Philometridae) from marine fishes off South Carolina. J. Parasitol. 95: 722-727.

Moravec F., de Buron I., Baker T.G., González-Solís D. 2008c: Some gonad-infecting species of Philometra (Nematoda, Philometridae) from offshore fishes of South Carolina and Georgia, USA, including Philometra charlestonensis sp. nov. from the scamp Mycteroperca phenax. Acta Parasitol. 53: 382-391.

Moravec F., Dyková I., De Buron I. 2009b: Female morphology of Philometra rubra (Nematoda: Philometridae), a parasite of the abdominal cavity of the striped sea-bass Morone saxatilis (Moronidae, Perciformes) in the USA. Folia Parasitol. 56: 64-66.

Moravec F., Fajer-Avila E.J., Bakenhaster M. 2010: Philometra floridensis sp. n. (Nematoda: Philometridae) from the ovary of red drum Sciaenops ocellatus (Osteichthyes: Sciaenidae) off the coast of Florida, USA. J. Helminthol. (In press.)

Moravec F., Gaglio G., Panebianco A., Giannetto S. 2008a: Two species of Philometra (Nematoda: Philometridae) from sparid fishes (porgies) off Sicily, Italy, including Philometra obladae sp. n. from the body cavity of Oblada melanura (Sparidae). Parasitol. Res. 104: 55-61.

Moranec F., Genc E. 2004: Redescription of three Philometra spp. (Nematoda, Philometridae) from the gonads of marine perciform fishes of Iskenderun Bay (North-East Mediterranean), Turkey. Acta Parasitol. 49: 31-40.

Moravec F., Justine J.-L. 2008: Some philometrid nematodes (Philometridae), including four new species of Philometra, from marine fishes off New Caledonia. Acta Parasitol. 53: 369-381.

Moravec F., Justine J.-L. 2009: New data on dracunculoid nematodes from fishes off New Caledonia, including four new species of Philometra (Philometridae) and Ichthyofilaria (Guyanemidae). Folia Parasitol. 56: 129-142.

Moravec F., Magi M., Macchioni F. 2008b: Redescription of the gonad-infecting nematode Philometra saltatrix Ramachandran, 1973 (Philometridae) based on specimens from the type host Pomatomus saltatrix (L.) (Osteichthyes) from the Tuscan Sea, Italy. Folia Parasitol. 55: 219-223.

Orecchia P., Paggi L. 1978: Aspetti di sistematica e di ecologia degli elminti parassiti di pesci marini studiati presso l'Istituto di Parassitologia dell'Università di Roma. Parassitologia 20: 73-89.

Quiazon K.M.A, Yoshinaga T., Ogawa K. 2008a: Taxonomical study into two new species of Philometra (Nematoda: Philometridae) previously identified as Philometra lateolabracis (Yamaguti, 1935). Folia Parasitol. 55: 29-41.

Quiazon K.M.A., Yoshinaga T., Ogawa K. 2008b: Philometra sawara sp. n. and a redescription of Philometra sciaenae Yamaguti, 1941 and Philometra nemipteri Luo, 2001 (Nematoda: Philometridae): a morphological and molecular approach. Folia Parasitol. 55: 277-290.

Stossich M. 1896: Ricerche elmintologiche. Boll. Soc. Adriat. Sci. Nat. 17: 121-136.

Received 7 August 2009

Accepted 9 October 2009 